\title{
When Is Bad News Really Bad News?
}

\author{
Jennifer Conrad \\ Kenan-Flagler Business School \\ University of North Carolina at Chapel Hill \\ Bradford Cornell* \\ Anderson Graduate School of Management \\ University of California, Los Angeles \\ Wayne R. Landsman \\ Kenan-Flagler Business School \\ University of North Carolina at Chapel Hill
}

July 2000

\begin{abstract}
We examine whether the asymmetrical price response to bad and good earnings shocks changes as the relative level of the market changes. The study is based on a sample of 24,108 announcements of firms' annual earnings during the period 1988 to 1998. The level of the market is a relative measure based on the difference between the market P/E at the end of the announcement month and the average market $\mathrm{P} / \mathrm{E}$ over the prior 12 months. Predictions based on behavioral finance models and extended regime-shifting models suggest that stock prices should respond more strongly to negative news as the relative market level rises. Similarly, prices should respond more strongly to good news in bad times, although the effect should be somewhat attenuated if the regime-shifting models are descriptively valid. The findings generally support these predictions.
\end{abstract}

Key words: $\quad$ Earnings response coefficients, pricing anomalies, value/glamour stocks. JEL classifications: G14, M41.

*Corresponding author. We thank IBES for providing earnings forecasts, Brian Rountree for research assistance, and workshop participants at UCLA, Bill Beaver, an anonymous referee, and René Stultz (editor) for helpful comments. We appreciate funding from the Center for Finance and Accounting Research at UNC-Chapel Hill, and the Bank of America Research Fellowship (Landsman). 


\section{Introduction}

One of the longest running empirical debates in finance regards the relative pricing of "value" and "glamour" stocks. Beginning with early work by Basu (1983) and Stattman (1980), evidence has accumulated that excess returns on value stocks, that is the issues of companies for which the ratio of earnings, cash flow or book value per share is large relative to stock price, are greater than returns on glamour stocks for which these ratios are small. On one side, Fama and French $(1992,1993,1995,1996)$ have argued that the observed differential between the returns on value and glamour stocks represents a risk premium. The alternative view, articulated by Lakonishok, Shleifer and Vishny (LSV, 1994), is that the market fails to price efficiently value and glamour stocks.

Extending LSV, recent work in behavioral finance such as Barberis, Shleifer and Vishny (BSV, 1998) and Daniel, Hirshleifer and Subrahmanyan (1998) argues that the value/glamour effect is the result of investor psychology. In particular, the model in BSV allows for investor underreaction (in the intermediate term) to single shocks, and investor overreaction (in the longer term) to a series of shocks. This model also implies an asymmetry in the returns to value and glamour stocks following a news shock. Following a string of positive shocks observed in, say, glamour stocks, the investor in this model expects another positive shock-that is, he expects the earnings to trend. If good news is announced, the market response is relatively small since the positive shock was anticipated. A negative shock, on the other hand, generates a large negative return since it is more of a surprise.

The primary empirical tests of the competing explanations for the value/glamour differential have been conducted on earnings announcements (LaPorta, 1996; Dechow Sloan, 1997). LaPorta, Lakonishok, Shleifer and Vishny (LLSV, 1997) and Bernard, Thomas, and Wahlen (1997) find that 
earnings announcement returns explain almost half of the return differential between value and glamour stock. More recently, Skinner and Sloan (1998) use a sample of earnings announcements and find that when pre-announcement effects are included, the differential reaction to earnings announcements completely explains the differential returns to value and glamour stocks. In addition, Skinner and Sloan also find evidence consistent with the BSV hypothesis. In particular, they find that the response to news is asymmetric for value and glamour stocks; the market reacts more strongly to bad news for both types of firms, but the reaction to bad news for glamour stocks over the subsequent 20 quarters is much larger.

In the BSV model, the source of uncertainty is the model of earnings for a particular firm, and hence is firm-specific. Thus this model can be used to explain a cross-sectional puzzle: why do value stocks (or, more generally, stocks which have underperformed in the past) appear to outperform glamour stocks (or stocks which have outperformed in the past) over time. More recently, however, there is some anecdotal evidence that market-wide "glamour" effects also are possible. For example, in the October 12, 1996 Wall Street Journal, Deborah Lohse speculated that the asymmetrical response of stock prices to good and bad news is related to the level of the market: ${ }^{1}$

Analysts say that stocks that surprise analysts with better-than-expected earnings are often rewarded with a ho-hum increase if any. However, the market is punishing stocks even more than usual for earnings disappointments... Part of the problem is fear of the valuation levels that many stocks have reached. With the market at these levels, if stocks are slightly down, (in terms of unexpected earnings) they get severely punished. [emphasis added]

\footnotetext{
1 “Amid a Rally, Underachievers Get Pummeled,” Wall Street Journal, October 12, 1996.
} 
The Wall Street Journal quote implies that the behavioral models can be extended from the firmspecific level to an aggregate level. Specifically, there are systematic shifts in investor sentiment that are common across stocks. That is, during good times, investors extrapolate good news for companies generally. However, firms providing specific information that the extrapolation of good news is not applicable to them are severely punished. During bad times, the reverse reaction occurs.

The notion that the market responds more strongly to bad news in good times does not necessarily require the assumption of irrationality or over-reaction on the part of investors that underlies much of the value/glamour literature. For example, regime-switching models, such as those developed by David (1997) and Veronesi (1999), offer a rational explanation for the market responding more strongly to bad news than good news in good times. In these models, investors are uncertain about the overall state of the market. Because investors cannot observe the current state of the market directly, they must infer it from past market performance. Following a long period of superior market performance, investors will become highly confident the market is in a good state. Under such circumstances, further good news has little impact on investor beliefs. However, bad news causes market prices to fall for two reasons. First, bad news causes investors to infer a lower probability that the market is in the good state. Second, as uncertainty in the state of the economy increases, risk-averse investors require a higher expected rate of return to hold stocks, and the market discount rate rises. ${ }^{2}$

\footnotetext{
${ }^{2}$ It should be noted that the regime shifting models are not directly applicable to the firm-specific empirical results presented here. The discount rate effect in the regime shifting models operates through the market risk premium. Therefore, it will be affected by market wide information. Individual firm announcements may or may not provide market wide information. Furthermore, not all individual firm announcements will carry the same amount of market
} 
The uncertainty about the state of the economy causes an asymmetry in the response to good news and bad news. That is, when investors believe that the economy is in the "bad" state and good news arrives, this increases the inferred probability that the market is in a good state; thus, the positive impact on prices is offset by the rising discount rate generated by increased investor uncertainty.

The regime-switching models discussed above are designed to describe aggregate market phenomena, not firm-specific responses in different market environments. In principle, such models could be extended to permit firm-specific reactions. ${ }^{3}$ In this paper, we motivate such research by examining whether the strength of firm-specific responses to new information is affected by the aggregate level of the market. Both the regime-shifting models and the behavioral literature suggest a time series analysis of the reaction of stock prices to both good and bad news in relation to the level of the market.

In the foregoing discussion, the notion of what defines good times or a high market is not precisely defined. Clearly, as a result of both inflation and real economic growth, the level of the market must be measured relative to some benchmark such as earnings or dividends. In this paper, earnings are used to benchmark the level of prices.

Selecting a benchmark does not resolve all the ambiguity related to the level of the market. When the behavioral and regime shifting models refer to good times does that mean good times in the absolute sense or relative to recent experience? More specifically, should the absolute priceearnings (hereafter P/E) ratio be used to define the level of the market or should the level be

information. An announcement by IBM will typically convey more information about general market conditions than an announcement by a small firm. 
defined by the relation between the current $\mathrm{P} / \mathrm{E}$ ratio and the ratio observed in the recent past? In this paper, the latter, relative, definition of the level of the market is employed. In particular, the level of the market is measured by comparing the value-weighted average market P/E ratio at the end of each firm-announcement month to the monthly average market P/E observed during the previous 12 months. In every case, the measure of earnings used is next year's forecasted earnings.

The "relative" definition of the level of the market is chosen over the "absolute" definition for several reasons. To begin, it is more consistent with the behavioral models that are based on the extrapolation of recent shocks. More fundamentally, an ARIMA analysis of the price-earnings ratio during the sample period of our study, 1987 to 1998, reveals that the P/E ratio is closely approximated by a random walk with positive drift. See Figure 1, which plots the monthly market $\mathrm{P} / \mathrm{E}$, the sample average $\mathrm{P} / \mathrm{E}$, and 12 month moving average (rolling) $\mathrm{P} / \mathrm{E}$ ratio. ${ }^{4}$ This fact has two implications. First, forming portfolios on the basis of the absolute level of $\mathrm{P} / \mathrm{E}$ becomes equivalent, at least in this sample period, to forming them on the basis of time. The low P/E portfolios would consist almost exclusively of observations from the late 1980s and early 1990s, while the high P/E portfolio would include almost exclusively observations from 1997 and 1998. Second, it implies that changes in the P/E ratio during the sample period are permanent. For both of these reasons, it is more appropriate to measure the level of the market relative to recent experience rather than in absolute terms. It is more difficult to assess which measure is more appropriate in the context of the regime shifting models because the relation between the regimes and the actual behavior of

\footnotetext{
${ }^{3}$ In correspondence, Veronesi indicates that he is currently developing one such model based on a generalization of his aggregate market model.

${ }^{4}$ After differencing the monthly market P/E series, a test of the residuals to lag twelve does not reject the null hypothesis of white noise ( $\mathrm{p}$-value $=0.929)$.
} 
stock prices is not spelled out in the theoretical models. Nonetheless, given the time series

properties of the $\mathrm{P} / \mathrm{E}$ ratio, it seems more appropriate to define the level of the market in relation to recent experience.

To explore whether the reaction of stock prices to earnings shocks is affected by the level of the market, we examine whether the earnings response coefficients for good and bad earnings shocks change as the relative level of the market changes. The study is based on a sample of 24,108 announcements of firms' annual earnings during the period 1988 to 1998 . The level of the market is defined by the variable, DIFFPE, which is the difference between the market P/E ratio and the average P/E during the preceding 12 months. If the research cited previously and the Wall Street Journal suggestion are correct, stock prices should respond more strongly to negative news as DIFFPE rises (or as relative market valuations increase). Similarly, prices should respond more strongly to good news in bad times, though the effect should be somewhat attenuated if the regime shifting models are correct. The findings generally support the hypothesis that stock prices respond most strongly to bad news in good times. In particular, the stock price response to negative earnings surprises is monotonically increasing as DIFFPE rises. The results for good news are more ambiguous, although findings are weakly consistent with the notion that the stock price response to positive earnings surprises is decreasing as DIFFPE rises. However, consistent with predictions of regime-shifting models, the difference between bad news and good news response coefficients is increasing across the DIFFPE portfolios. Findings based on subsamples of NASDAQ and NYSE stocks indicate that pricing effects are more pronounced for NASDAQ stocks.

The regime-shifting models apply to all stocks equally. If, however, the asymmetric response to good and bad news is caused in part by "irrational" exuberance in good times, then it is 
possible that the effect is more pronounced for glamour than for value stocks. To see whether there is an interaction between our time series analysis and the cross-sectional findings cited above, we partition our sample into quintiles based on each firm's ratio of price to earnings in the month preceding announcement of earnings. We then examine whether changes in the asymmetry between good and bad news over time is different for glamour and value stocks. The findings fail to indicate any significant difference in the behavior of value and glamour stocks.

The paper proceeds as follows. Section 2 describes the research design and explains our hypotheses. Section 3 describes the data and sample. Section 4 provides the paper's findings and section 5 summarizes and concludes the study.

\section{Research Design}

The discussion in the preceding section suggests examining two hypotheses. The first is that the market responds asymmetrically to unexpected good and bad earnings news in good and bad states. Bernard, Thomas, and Wahlen (1997), LLSV (1997), and Skinner and Sloan (1998) document substantial differences in the responses to good and bad earnings shocks. However, these studies examine exclusively mean returns for periods subsequent to announcement of earnings. In contrast, we focus on the elasticity of stock prices to earnings surprises at announcement, i.e., earnings response coefficients. Specifically, we estimate regressions which allow for a differential response to positive and negative earnings in the overall sample. In this regard, we create two indicator variables. The first, $U P$, is set equal to one if the shock is positive, and zero otherwise; the second, $D O W N$, is equal to one if the shock is negative and zero otherwise. We then estimate two regressions of the form,

$$
R E T_{i t}=a_{0}+a_{1} U E_{i t}+a_{2} S I Z E_{i t}+\varepsilon_{i t},
$$

and 


$$
\operatorname{RET}_{i t}=b_{0}+b_{1} U E U P_{i t}+b_{2} U E D O W N_{i t}+b_{3} S_{Z I Z E_{i t}}+\varepsilon_{i t} .
$$

In equations (1) and (2), $R E T_{i t}$ is the excess return on firm $i$ during the earnings announcement period as defined below and $U E_{i t}$ is the unexpected earnings for firm $i$ at time $t$ computed using the $\mathrm{I} / \mathrm{B} / \mathrm{E} / \mathrm{S}$ data to measure expectations. In equation (2), UEUP (UEDOWN) is the product of unexpected earnings, $U E$, and the indicator variable, $U P(D O W N)$; this permits the slope on $U E$ to be different conditional on the sign of the earnings surprise. SIZE is the natural log of equity market value in the period prior to the firm's earnings announcement (see footnote 7). The intercept in each equation is the mean excess return in the announcement period for firms with $U E=0$. The size proxy is included to control for risk differences not already reflected in excess return (Fama and French, 1991) and for potential scale differences (Barth and Kallapur, 1996). If the market response to good and bad earnings innovations is asymmetric then equation (2) should have significantly more explanatory power than equation (1) and the hypothesis that $b_{1}=b_{2}$ should be rejected.

The second, and more innovative, hypothesis is that the degree of asymmetry depends on the level of the market. To investigate this hypothesis we use the ratio of price to forecasted future earnings to measure the relative level of the market. More specifically, using DIFFPE, the sample of earnings announcements is divided into quintiles. The first quintile contains the earnings announcements that occurred when DIFFPE is the lowest. The other quintiles contain earnings announcements that occurred when DIFFPE is progressively larger. If the announcement asymmetry depends on the level of the market then the difference between $b_{1}$ and $b_{2}$ should change as equation (2) is estimated for quintiles defined by progressively greater levels of DIFFPE.

Finally, it is possible that the time series hypotheses examined here interact with the crosssectional value/glamour effects documented in the literature reviewed in the previous section. 
More specifically, the asymmetry between the response to good and bad news may vary both over time and across stocks with the relative sensitivity to bad news being more pronounced for glamour stocks in good times and less pronounced for value stocks in bad times. To test for this interaction, we sort individual companies into quintiles based on each firm's P/E ratio in the month preceding its earnings announcement, where the ratio is based on next year's forecasted earnings. The companies in the lowest quintile are the "value" stocks and the companies in the highest quintile are the "glamour" stocks. Using these definitions we test whether the asymmetry varies crosssectionally as well as over time.

\section{Data}

Our sample period extends from 1988 through 1998. Consensus earnings forecasts, realized earnings and earnings report dates are collected from I/B/E/S. For each earnings announcement, we define an event window which extends from day -20 through 0 relative to the earnings report date. This window is divided into a pre-announcement period, extending from day -20 through day -6 , and an announcement period, extending from day -5 through day 0 . These earnings data are subsequently matched with price, shares and returns data from the Center for Research in Security Prices (CRSP). For each firm and each report date, raw returns are summed across the event window; excess returns are calculated as the sum of the firm's raw returns during the event window less the sum of the CRSP value-weighted market return over the same period. ${ }^{5} \mathrm{~A}$ firm must have a price available on the earnings report date to be included in the sample. To analyze the price

\footnotetext{
5 As a specification check, we also examine excess compounded returns, which minimize bid-ask bias; these excess returns are calculated as the compounded raw return in the announcement (pre-announcement) period, less the compounded market return over the same interval. As discussed in section 4.3 below, findings are essentially identical to those reported.
} 
impact of an earnings shock in the announcement period, unexpected earnings, $U E$, (or earnings shocks) are calculated as:

$$
U E=(\text { Actual earnings }- \text { consensus forecast earnings }) / \text { Price }(-6)
$$

where Price(-6) is the share price six days before the earnings announcement (or one day prior to the announcement window). ${ }^{6}$

To reduce the impact of outliers, if the earnings shock is greater than (less than) $0.5(-0.5)$, then the value of the earnings shock is winsorized to $0.5(-0.5)$. To minimize the effect of market frictions (see, e.g., Ball, Kothari and Shanken (1993)), observations with Price(-6) (Price (-20)) in the announcement (pre-announcement) window of less than $\$ 5.00$ are deleted. To remove the impact of stock splits or stock dividends in the event window, we delete observations where the number of shares outstanding 20 days prior to the earnings announcement differs from shares outstanding on the announcement date. Consistent with prior research showing earnings response coefficients are essentially zero for firms reporting negative earnings (e.g., Hayn (1995) and Lipe, Bryant, and Widener (1998)), observations where firms report negative earnings are deleted. Finally, observations for which the ratio of actual earnings to market capitalization on day zero exceeds one are also deleted.

To categorize whether the earnings announcement occurred in a 'high' or 'low' valuation state, a monthly time-series of market price/earnings ratios are estimated using the $\mathrm{I} / \mathrm{B} / \mathrm{E} / \mathrm{S}$ data. To calculate the market $\mathrm{P} / \mathrm{E}$ for a particular month $t$, we first collect the consensus earnings forecast for the next fiscal year made in month $t$ for each firm, as well as the observed price in month $t$ for that

\footnotetext{
${ }^{6}$ As an additional specification check, we examine the period extending from day -20 to day -6 to test for preannouncement leakage, particularly for bad news (Skinner and Sloan, 1998). For these specifications, earnings shocks are standardized by the price on day -20 .
} 
firm. We construct a value-weighted average of the earnings-to-price ratio across firms, then take the reciprocal of this number as the market price-earnings ratio. Thus, we calculate:

$$
P / E(m k t)_{t}=1 /\left[\sum_{i=\{1, N t\}} w_{i t}\left(\mathrm{E}_{t}\left[E P S_{i \tau}\right] / P_{i t}\right)\right],
$$

where $w_{i t}$ is the value of firm $i$ relative to the total market value of firms available in the sample for month $t, P_{i t}$ is the share price of firm $i$ in month $t$, and $\mathrm{E}_{t}\left(E P S_{i \tau}\right)$ is the consensus analysts' forecast in month $t$ for annual earnings reported in month $\tau$. Firms are deleted from the average if they do not have price, forecasted earnings or shares outstanding numbers available; only earnings forecasts less than one year old are considered when constructing this average (that is, $\tau$ must be no more than 12 months distant from $t$.).

After the time-series of market price/earnings ratios is constructed, DIFFPE, the difference between each month's market price/earnings ratio and the average of the market's monthly price/earnings ratio over the previous 12 months' period is calculated. Earnings announcements are then grouped into one of five portfolios based on the value of this difference as of the announcement month. The mean DIFFPE for the five portfolios are $-1.45,0.01,0.62,1.09$ and 1.99. Note that although the sample period of earnings announcements extends from 1988 through 1998, because DIFFPE is based on the difference between the announcement month's market P/E and the average market $\mathrm{P} / \mathrm{E}$ over the prior 12 months, the $P / E(m k t)_{t}$ series extends back an additional year to 1987 .

\section{Findings}

\subsection{Descriptive Statistics}

Table 1, panel A, presents sample descriptive statistics for earnings surprises, $U E_{i t}$, and earnings response coefficients and adjusted $\mathrm{R}^{2}$ values from a regression of excess returns, $R E T_{i t}$, and $U E_{i t}$, in equation (1). Consistent with prior research indicating analysts are optimistically 
biased (O'Brien, 1988, Kang et al., 1994), mean UE is negative. However, when we examine average earnings shocks by year, we find that the largest negative shocks occur, on average, in the early part of our sample period. For example, three out of the seven years between 1992 and 1998 have positive average shocks, with the 1997 mean $U E$ significantly positive and averaging $0.05 \%$ of the stock price. The sample average earnings response coefficient of 0.20 is significant and also is comparable to that found in prior research (Brown et al, 1987). ${ }^{7}$ Finally, mean excess return, $R E T$, is approximately zero, which is expected given that mean $U E$ is economically small.

Table 1, panel B, presents findings analogous to those in panel A, but broken down by sign of earnings surprise. Mean positive unexpected earnings, $U E U P$, and negative unexpected earnings, UEDOWN, are of similar magnitude, 0.0067 and -0.0098 . Untabulated findings indicate no major trends in their magnitude differences, although the number of $U E U P(U E D O W N)$ is generally rising (declining) during the sample period. The largest difference is in 1989, when mean $U E D O W N$ is -0.007 and mean $U E U P$ is 0.005 .

The earnings response coefficients corresponding to positive and negative earnings shocks, $b_{1}$ and $b_{2}$ from equation (2), are 0.17 and 0.24 , and they are marginally significantly different (pvalue $=0.09$ ), indicating a weak asymmetry in the market's response to good and bad news. Consistent with this finding, the adjusted $\mathrm{R}^{2}$ of 0.56 percent, is identical to the value associated with equation (1) in which $b_{1}$ and $b_{2}$ are constrained to be equal. This finding is only weakly consistent with Skinner and Sloan (1998) who find an asymmetry in mean security returns for positive and negative earnings surprises, unconditional on the magnitude of the earnings surprise. Finally, mean excess return, RET, is $0.0154,0.0058$, and -0.0059 for positive, zero, and negative

\footnotetext{
${ }^{7}$ Throughout the paper, we use a five percent criterion for assessing statistical significance.
} 
unexpected earnings subsamples, indicating that the mean return difference for negative and zero $U E$ firms, $1.17 \%$, is larger than that for the positive and zero $U E$ firms, $0.96 \%$.

Before turning to findings from estimations of equations (1) and (2) for the separate market $\mathrm{P} / \mathrm{E}$ portfolios, it is useful to extend the earlier analysis on the time series characteristics of the market during our sample period. Table 2 provides a description of the level of the market over time as measured by our forward-looking weighted average price-earnings multiple. Panel A presents statistics for market PE as well as DIFFPE, the difference between market prevailing during firm-announcement months and the average market PE during the prior 12 months. Mean annual PE is just the average for the twelve calendar months. Although mean PE is generally rising during the 1990's, it clearly is not monotonic, falling from an average of 17.80 in 1994 to 15.97 in 1995. Mean market PE values rise to their highest levels in 1997 and 1998, reflecting the booming stock prices during this period.

Mean annual DIFFPE is computed as the mean DIFFPE for the sample firmannouncements during a given year, not the simple monthly mean difference in market PE and average market PE for the prior 12 months. In contrast to PE, mean DIFFPE exhibits no apparent secular trend. This is because DIFFPE is a relative measure reflecting the difference between the level of the market when earnings are announced and the recent (12 month) historical level of the market. However, as with PE, the maximum mean annual DIFFPE also appears in 1998, when the market is at historically high levels.

The annual standard deviation in DIFFPE ranges from 0.47 in 1996 to 1.38 in 1991, indicating there is within-year variation in DIFFPE. Stated another way, firm-announcements from particular years will not necessarily all be placed within one specific DIFFPE group, of which there are five. Table 2, panel B, lists the number of firms within each DIFFPE portfolio for each 
sample year. High DIFFPE firm-announcements $(D I F F P E=4$ and 5) are bunched disproportionately in 1998, when the market is at its historically high level. However, in the prior year, 1997, when the market PE is second only to 1998 , there are nearly as many middle range DIFFPE firm-announcements as there are high ones. With the exception of the two lowest DIFFPE categories in 1993 and the highest DIFFPE categories in 1988, firm-announcements span the DIFFPE categories in each sample year.

Table 3, panel A, presents unexpected earnings statistics for the five DIFFPE portfolios for the full sample. Panel B presents analogous statistics but broken down by the sign of unexpected earnings. Panel A reveals a monotonic increase in earnings shocks across the five portfolios, ranging from a mean of -0.0013 in DIFFPE portfolio 1 to 0.0002 for portfolio 5. Panel B reveals no apparent pattern in the magnitude of positive and negative shocks across the five portfolios

\subsection{Regression results for DIFFPE portfolios}

We now turn to the primary hypothesis of our study, that the difference between earnings response coefficients, $b_{1}$ and $b_{2}$ in equation (2), should increase with the valuation level of the market. Table 4, panels A and B, presents the regression summary statistics corresponding to equations (1) and (2) for each of the DIFFPE portfolios. $^{8}$ The findings for equation (1) in panel A, in which $b_{1}$ and $b_{2}$ are constrained to be equal, indicate no apparent trend in the $U E$ response coefficients, $\mathrm{a}_{1}$. The highest $\mathrm{a}_{1}$ estimates obtain for middle and highest DIFFPE portfolios. All response coefficients are significantly positive.

\footnotetext{
${ }^{8}$ The regression sample of 24,077, which is 31 less than the sample of firm-announcements used in tables 1 through 3 , results from the additional data requirement of available market value data to compute the size variable, $\log (\mathrm{mve})$. The market value information is calculated at day -6 ; if this value is missing, we use the day -7 value, then day -8 and so on. If the value is still missing at day -10 , we use the value at day -1 .
} 
The evidence in table 4, panel B, reveals a striking difference in the pattern of response coefficients for positive and negative earnings surprises. For ease of comparison, the UEUP and UEDOWN coefficients across the five DIFFPE portfolios are plotted in figure 2, and their differences are plotted in figure 3. Looking first at the negative earnings surprises, the coefficients on $U E D O W N, \mathrm{~b}_{2}$, are all significantly positive. More importantly, the response coefficients increase monotonically across the five DIFFPE groupings. This finding suggests that the market reacts more strongly to bad news as market levels rise and is consistent with predictions of both the regime shifting models and behavioral models.

In contrast to the negative earnings surprises, the UEUP response coefficients, $\mathrm{b}_{1}$, exhibit no apparent trend. As depicted in figure 2, the pattern of $b_{1}$ values exhibits a W-shape with a slight overall decline from the high of 0.25 for the lowest DIFFPE portfolio to a value of 0.20 for the highest DIFFPE portfolio. Also in contrast to the negative earnings shocks, not all of the positive earnings surprise response coefficients are significant. With the exception of the DIFFPE=3 portfolio, the market appears to find positive earnings surprises relatively uninformative when market levels are consistent with expectations. To the extent there is a slight downward trend in positive earnings response coefficients, this is consistent with predictions of the regime-shifting models which posit good news is more informative in down markets than up markets.

The key prediction of extended regime-shifting models relates to the expected pattern in the difference in market responses to bad news and good news. In up markets (i.e., when DIFFPE=5), bad news conveys both negative future cash flow implications as well as an increase in uncertainty and an increase in the discount rate; good news conveys little information regarding either cash flow or uncertainty. In down markets (i.e., when $D I F F P E=1$ ), good news conveys positive future cash flow implications. However, the positive reaction is dampened by an increase in uncertainty 
and the discount rate. Bad news conveys little information regarding either cash flow or uncertainty. Thus, the difference between bad news and good news response coefficients in up markets should exceed the difference between the good news and bad news response coefficients in down markets. Alternatively stated, the difference between bad news and good news response coefficients should be increasing across the DIFFPE portfolios. The plot of this difference, depicted in figure 3, indicates our findings generally are consistent with the regime-shifting model prediction. The difference in $U E D O W N$ and $U E U P$ coefficients rises from -0.089 in the $D I F F P E=1$ portfolio, to 0.161 in the $D I F F P E=5$ portfolio. A regression of the coefficient differences on DIFFPE indicates the slope is significantly positive (p-value $=0.05$ under a one-sided alternative). With the exception of the drop from $D I F F P E=4$ to $D I F F P E=5$, the difference increases across all portfolios.

The results are also consistent with the broad predictions of the behavioral models. Presumably the greater the relative increase in stock prices, the more pronounced are investors' extrapolations and the greater the impact of unexpected bad news. Unlike, the regime shifting models however, the behavioral models predict a reverse, but symmetric impact, when stock prices fall. This prediction is not consistent with the findings.

\subsubsection{Value-Glamour}

One strand of the value/glamour literature reviewed in the first section suggests that greater average returns on value as compared to glamour stocks returns is attributable to the tendency of analysts and/or investors to extrapolate irrationally past corporate performance. As a result, glamour stocks with historically high growth rates tend to become overpriced. When bad news finally reveals to investors the error of their ways, the prices of glamour stocks fall sharply. 
If the irrational extrapolation theory is correct, then it should be the case that as the market rises the asymmetry in the response to good and bad news becomes relatively more pronounced for glamour stocks. To assess whether this is the case, we examine how the asymmetrical response to good and bad news varies across stocks as well as over time. Specifically, we sort individual companies into quintiles based on their $\mathrm{P} / \mathrm{E}$ ratios in the month preceding each firm announcement, where earnings is based on next year's forecasted earnings. The companies in the lowest quintile are the "value" stocks and the companies in the highest quintile are the "glamour" stocks. ${ }^{9}$ We then reestimate equations (1) and (2) for each of the five DIFFPE groupings, permitting the coefficients of $U E U P$ and $U E D O W N$ to vary for value stocks (quintile 1) and glamour stocks (quintile 5) and average stocks (quintiles 2 through 4).

The results, which are not reported, fail to reveal any significant distinction between the behavior of value and glamour stocks. That is, the findings reported in table 4, panel B and depicted in figures 2 and 3 hold approximately equally for value and glamour stocks.

In light of the findings of Bernard, Thomas, and Wahlen (1997), LLSV (1997), and Skinner and Sloan (1998), our results are somewhat surprising. However, the studies are not directly comparable. Not only are the sample periods different, but we examine the response coefficients to unexpected good and bad news whereas the previous studies examined mean returns for periods following earnings announcements.

\subsubsection{NASDAQ vs. NYSE}

Although size is included as a control for risk in equations (1) and (2), it is possible that response effects could be more pronounced for NASDAQ than NYSE firms because of risk

\footnotetext{
${ }^{9}$ As LLSV (1997) report, the impact of the glamour/value distinction is relatively invariant to variables used to define it be they $\mathrm{E} / \mathrm{P}$, Book/Market, or some similar measure.
} 
differences for which we have not controlled. To explore this possibility, we re-estimate equations (1) and (2) separately for NASDAQ and NYSE firms.

Table 5, panels A and B, presents regression summary statistics for equations (1) and (2) for NASDAQ firms; table 6, panels A and B, presents regression summary statistics for equations (1) and (2) for NYSE firms. Inspection of findings in both tables indicate that the findings for the overall sample appear to generalize to both sets of firms. However, the pattern of increases in bad news response coefficients and decreases in good news response coefficients across the DIFFPE portfolios is markedly more pronounced for NASDAQ firms than NYSE firms. For example, whereas the $U E D O W N$ coefficients increase only 0.140 between the $D I F F P E=1$ and $D I F F P E=5$ portfolios for NYSE firms, for NASDAQ firms the $U E D O W N$ coefficients increase 0.595 between the same two portfolios. In fact, findings from separate regressions of UEUP and UEDOWN coefficients on DIFFPE cannot reject the null hypothesis of a slope of zero for NYSE firms. In contrast, analogous regressions for NASDAQ firms indicates the $U E D O W N$ coefficients are marginally increasing across the DIFFPE portfolios ( $\mathrm{p}$-value $=0.075$ under a one-sided alternative). More importantly, whereas for NASDAQ firms the difference between $U P D O W N$ and UEUP coefficients exhibits a significantly increasing slope in a manner consistent with figure 3 (pvalue $=0.007$ under a one-sided alternative), the difference in coefficients for NYSE firms exhibits no pattern. These findings suggest that the pricing effects are far more pronounced for NASDAQ firms than NYSE firms. However, during our sample, including 1997 and 1998, the aggregate stock returns of NASDAQ and NYSE stocks are not fundamentally different. For example, in the period 1997 through 1998, the difference in returns was only approximately 4\% (69\% vs. 65\%). Thus, the pricing difference for the two samples appears not to be a result of differences in stock 
price runups.. Developing a more complete understanding for the pricing differences is a challenge for future research.

\subsubsection{Other specification checks}

Skinner and Sloan (1998) find evidence of significant pre-announcement effects in their sample of earnings announcements. To test whether such effects are present in our sample, we examine the period extending from day -20 to day -6 . Consistent with Skinner and Sloan (1998), untabulated findings provide evidence of pre-announcement market responses, particularly for negative earnings shocks. However, adding the preannoucement earnings response coefficients to those from the announcement period does not alter the tenor of our reported findings.

Finally, as an additional specification check, we reestimated equations (1) and (2) for each of the DIFFPE portfolios compounding returns rather than cumulating them (Bernard and Thomas, 1989; and Conrad and Kaul, 1993). Not surprisingly given the relatively short window we examine (6 days in the announcement period and 15 days in the pre-announcement period), the results are virtually identical to those reported in table 4.

\section{Summary and Concluding Remarks}

Two separate strands of literature imply that as the level of the market rises, stock prices will become relatively more sensitive to bad news than good news. The first, based on research in behavioral psychology, suggests that investors inappropriately extrapolate past performance. As a result, bad news has a particularly telling impact after a period of good news because it has the effect of correcting overoptimistic projections. The second, based on extended regime shifting models, also predicts that the market will respond more strongly to bad news than good news when stock prices are high. 
To test the hypothesis that stock prices respond more strongly to bad news than good news when stock prices are high, we examine the reaction of stock prices to of 24,108 announcements of firms' annual earnings during the period 1988-98. Firm-announcements are placed into one of five portfolios based on a relative market level of the market measure, the difference between the current market P/E ratio and the average P/E during the preceding 12 months. We then examine the reaction of stock prices to both positive and negative earnings surprises for each portfolio separately.

The findings generally support the hypothesis that stock prices respond most strongly to bad news in good times. In particular, the stock price response to negative earnings surprises is monotonically increasing as the market level rises. The results for good news, while less strong, are consistent with the notion that the stock price response to positive earnings surprises is decreasing as the market level rises. However, consistent with predictions of regime-shifting models, the difference between bad news and good news response coefficients is increasing as the market level rises. Findings based on subsamples of NASDAQ and NYSE stocks indicate that pricing effects are more pronounced for NASDAQ stocks. Explaining this difference between the reaction of NASDAQ and NYSE firms is a challenge for future research. 


\section{References}

Ball, R., S.P. Kothari and J. Shanken. 1993, Problems in measuring portfolio performance: an application to contrarian investment strategies, Journal of Financial Economics 38, 1995, 79-107.

Barberis, N., A. Shleifer and R. Vishny, 1998, A model of investor sentiment, Journal of Financial Economics 49, 307-343.

Barth, M.E, and S. Kallapur, 1996, Effects of cross-sectional scale differences on regression results in empirical accounting research, Contemporary Accounting Research 13, 527567.

Basu, S., 1983, The relationship between earnings yield, market value, and return for NYSE common stocks: Further evidence, Journal of Financial Economics 12, 129-156.

Bernard, V., and J. Thomas, 1989, Post-earnings announcement drift: delayed price response or risk premium? Journal of Accounting Research Supplement, 1-36.

Bernard, V., J. Thomas and J. Wahlen, 1997, Accounting based stock price anomalies: Separating market inefficiencies from risk, Contemporary Accounting Research 14, 89-136.

Black, F., 1976, Studies of stock price volatility changes, Proceedings of the 1976 meetings of the Business and Economics Statistics Section, American Statistical Society.

Brown, L.D., R. L. Hagerman, P.A. Griffin, and M.E. Zmijewski, 1987, An evaluation of alternative proxies for the market's assessment of unexpected earnings, Journal of Accounting and Economics 9, 159-193. 
Conrad, J., and G. Kaul, 1993, Long-term overreaction or biases in computed returns? Journal of Finance 48, 39-63.

Daniel, K., and S. Titman, 1997, Evidence on the characteristics of cross-sectional variation in stock returns, Journal of Finance, 51, 1-34.

David, A., 1997, Fluctuating confidence in stock markets: implications for returns and volatility, Journal of Financial and Quantitative Analysis 32, 427-482.

Dechow, P.M. and R.G. Sloan, 1997, Returns to contrarian investment strategies: Tests of naïve expectations hypotheses, Journal of Financial Economics 43, 3-27.

Fama, E.F. and K.R. French, 1992, The cross section of expected stock returns, Journal of Finance 46, 427-466.

Fama, E.F. and K.R. French, 1993, Common risk factors in the returns on stocks and bonds, Journal of Financial Economics 33, 3-56.

Fama, E.F. and K.R. French, 1995, Size and book-to-market factors in earnings and stock returns, Journal of Finance 50, 131-155.

Fama, E.F. and K.R. French, 1996, Multifactor explanation of asset pricing anomalies, Journal of Finance 51, 55-84.

Hayn, C., 1995, The information content of losses, Journal of Accounting and Economics $20,125-153$.

Kahneman, D. and A. Tversky, 1982, Intuitive prediction: Biases and corrective procedures, in D. Kahneman, P. Slovic and A. Tversky eds., Judgment under uncertainty: Heuristics and biases, (Cambridge University Press, Cambridge).

Kang, S., J. O’Brien, K. Sivaramakrishna, 1994, Analysts’ interim earnings forecasts: evidence on the forecasting process," Journal of Accounting Research 32, 103-112. 
Kothari, S.P., J. Shanken and R.G. Sloan, 1995, Another look at the cross-section of expected returns, Journal of Finance 50, 185-224.

Lakonishok, J., A. Shleifer and R. Vishny, 1994, Contrarian investment, extrapolation and risk, Journal of Finance 49, 1541-1578.

La Porta, R., 1996, Expectations and the cross-section of expected returns, Journal of Finance 51, 1715-1742.

La Porta, R., J. Lakonishok, A. Shleifer and R. Vishny, 1997, Good news for value stocks: Further evidence on market efficiency, Journal of Finance 52, 859-874.

Lipe, R., L. Bryant, and S. Widener, 1998, Do nonlinearity, firm-specific coefficients, and losses represent distinct factors in the relation between stock returns and accounting earnings? Journal of Accounting and Economics 25, 195-214.

Lo, A.W. and A.C. MacKinlay, 1990, Data-snooping biases in tests of financial asset pricing models, Review of Financial Studies 3, 431-467.

O'Brien, P., 1988, Analysts' forecasts of earnings expectations," Journal of Accounting and Economics, 53-83.

Skinner, D.J., 1994, Why firms voluntarily disclose bad news, Journal of Accounting Research 32, 38-60.

Skinner, D.J. and R.G. Sloan, 1998, Earnings surprises, growth expectations and stock returns or Don't let an earnings torpedo sink your portfolio, unpublished working paper, University of Michigan Business School.

Soffer, L.C., S.R. Thiagarajan and B.R. Walther, 1998, Earnings preannouncements, unpublished working paper, Northwestern University. 
Stattman, D., 1980, Book values and stock returns, The Chicago MBA: A Journal of Selected Papers 4, 25-45.

Veronesi, P., 1999, Stock market overreaction to bad news in good times: a rational expectations equilibrium model, Review of Financial Studies, forthcoming.

Wall Street Journal, 1996, “Amid a rally, underachievers get pummeled,” October 12. 


\section{TABLE 1}

Unexpected earnings summary statistics and regression statistics for overall sample. Sample period is annual earnings for 1990-1998.

PANEL A: FULL SAMPLE

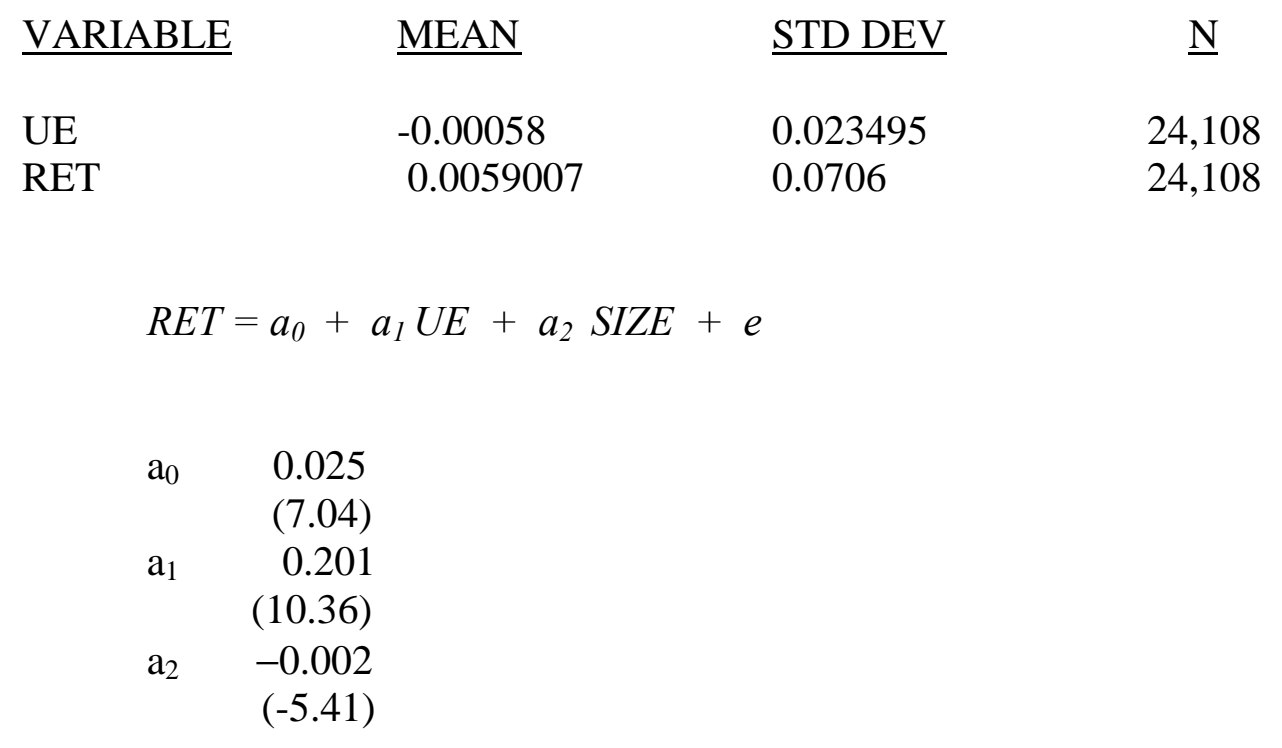

Adj. $R^{2} \quad 0.0056$ 


\section{TABLE 1}

PANEL B: SAMPLE PARTITIONED BY SIGN OF UNEXPECTED EARNINGS

$\underline{\mathrm{UE}>0}$

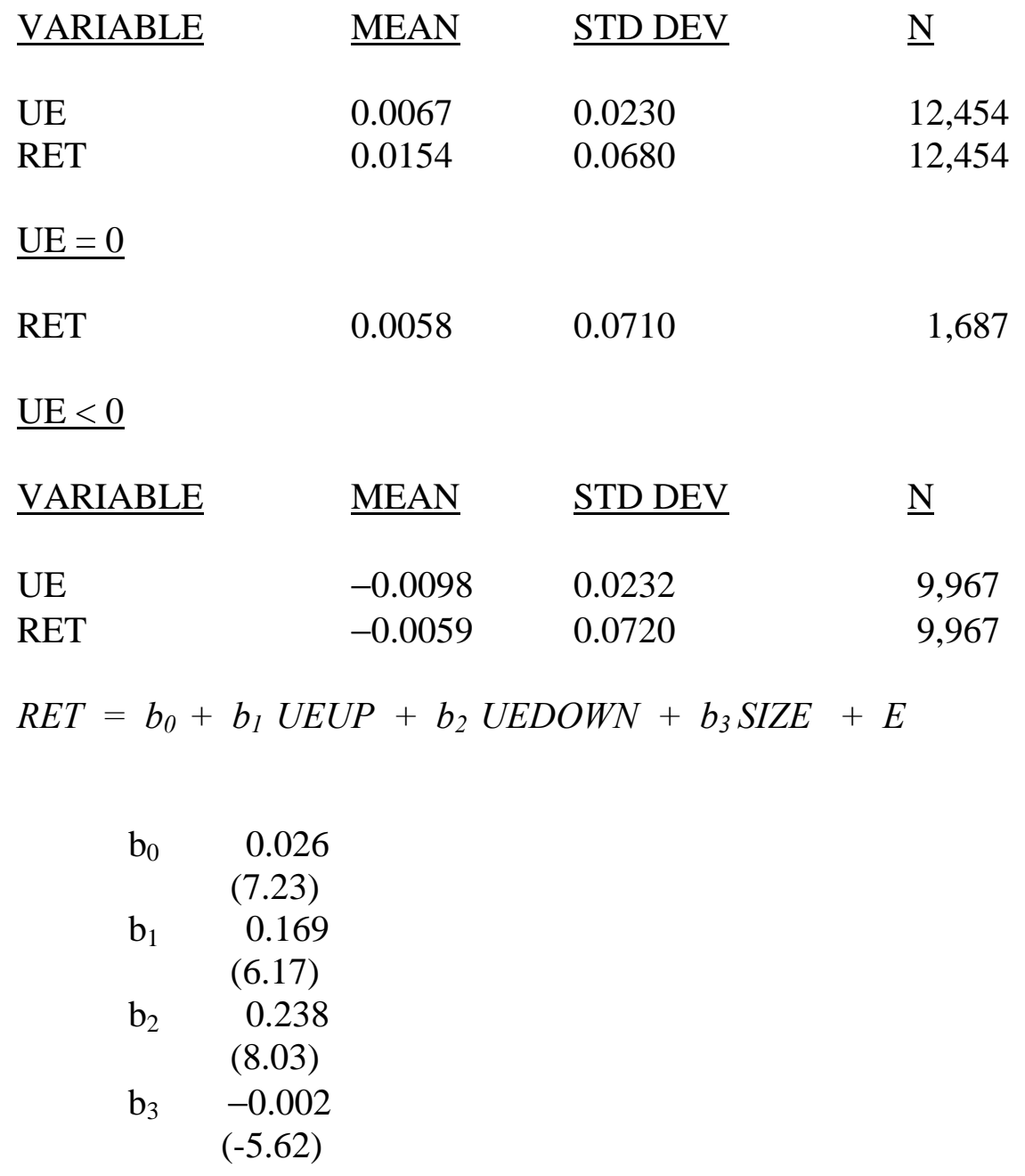

Adj. $R^{2} \quad 0.0056$ 


\section{TABLE 2}

PANEL A: market price-to-forecasted earnings, PE, and DIFFPE, summary statistics. Market PE statistics are based on end-of-month values. DIFFPE statistics are computed using DIFFPEs prevailing during each firm-announcement month.

Market PE

$\begin{array}{llllll} & \text { Mean } & \text { Std Dev } & \text { Max } & \text { Min } & \text { N } \\ 1988 & 11.599 & 0.464 & 12.740 & 10.913 & 1021 \\ 1989 & 11.961 & 0.767 & 14.037 & 11.295 & 1464 \\ 1990 & 12.681 & 0.606 & 13.700 & 11.327 & 1550 \\ 1991 & 13.809 & 1.744 & 17.044 & 11.527 & 1594 \\ 1992 & 16.021 & 0.864 & 17.883 & 14.631 & 1807 \\ 1993 & 16.992 & 0.889 & 18.950 & 16.142 & 2018 \\ 1994 & 17.805 & 0.956 & 19.595 & 16.097 & 2473 \\ 1995 & 15.967 & 0.618 & 17.695 & 15.332 & 2895 \\ 1996 & 16.560 & 0.499 & 18.808 & 16.592 & 2960 \\ 1997 & 19.193 & 1.115 & 21.614 & 17.437 & 3163 \\ 1998 & 21.762 & 0.976 & 24.342 & 20.585 & 3163\end{array}$

$\underline{\text { All years }}$

\section{Mean}

Std dev

Max

Min

\section{DIFFPE}

$\begin{array}{cccccc} & \text { Mean } & \text { Std Dev } & \text { Max } & \text { Min } & \text { N } \\ 1988 & -2.450 & 0.966 & -0.129 & -3.333 & 1021 \\ 1989 & 0.376 & 0.624 & 1.890 & -0.205 & 1464 \\ 1990 & 0.076 & 0.700 & 1.223 & -1.483 & 1550 \\ 1991 & 1.075 & 1.373 & 3.315 & -1.058 & 1594 \\ 1992 & 0.483 & 1.297 & 3.149 & -1.697 & 1807 \\ 1993 & 0.991 & 0.524 & 1.776 & 0.420 & 2018 \\ 1994 & 0.105 & 1.058 & 2.123 & -1.347 & 2473 \\ 1995 & -0.802 & 0.819 & 1.431 & -1.482 & 2895 \\ 1996 & 0.843 & 0.466 & 1.417 & -0.551 & 2960 \\ 1997 & 1.099 & 0.754 & 2.937 & -0.519 & 3163 \\ 1998 & 1.288 & 0.797 & 3.282 & -1.422 & 3163\end{array}$

16.842

3.064

24.342

10.913

\begin{tabular}{|c|c|}
\hline All years & \\
\hline Mean & 0.445 \\
\hline Std dev. & 1.237 \\
\hline Max & 3.315 \\
\hline Min & -3.333 \\
\hline
\end{tabular}


TABLE 2

Panel B: Distribution of Firm-announcements by Year and DIFFPE Portfolio

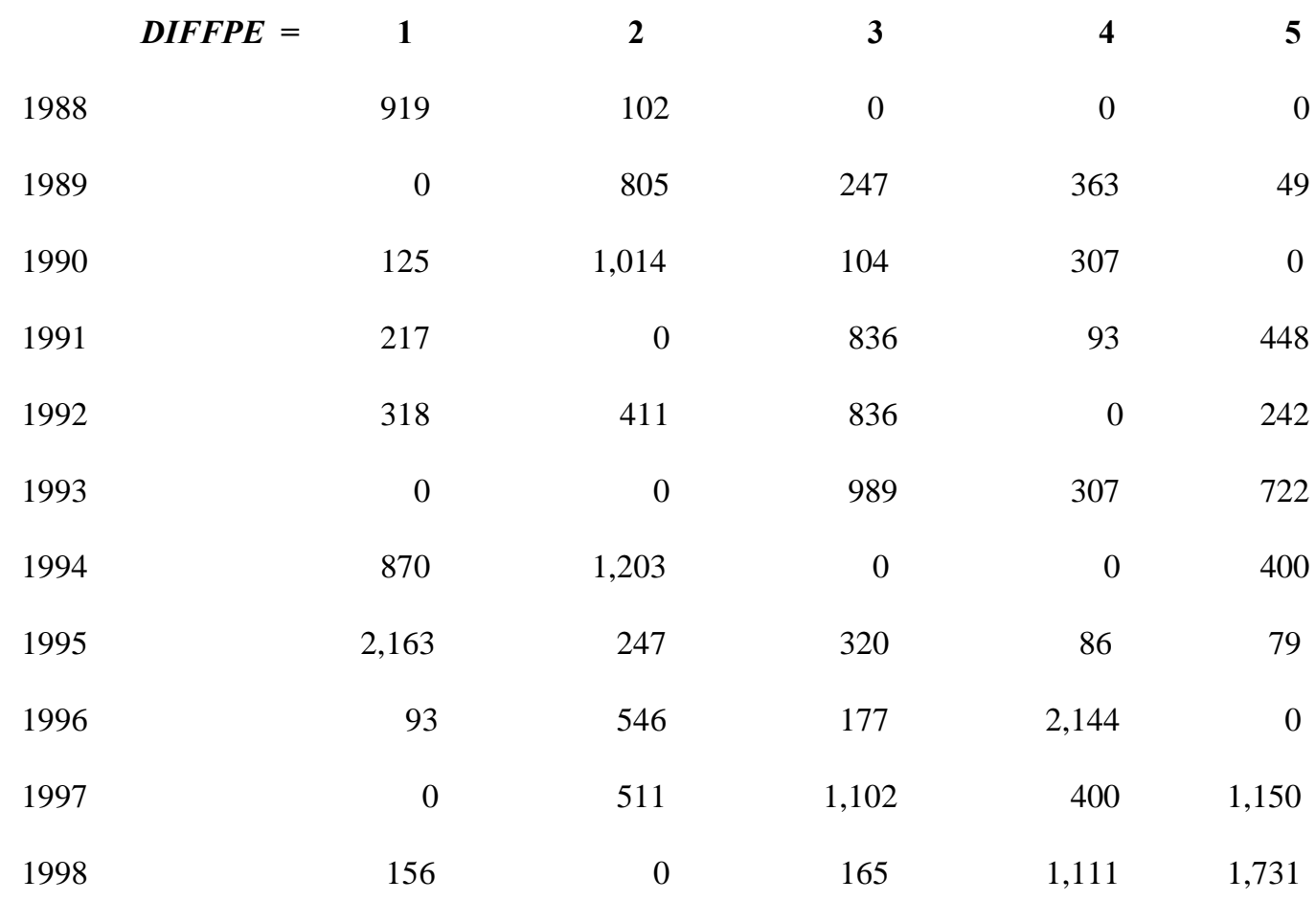




\section{TABLE 3}

PANEL A: Unexpected Earnings Overall Sample Unexpected Earnings Sample Summary Statistics by DIFFPE Portfolio

\begin{tabular}{|c|c|c|c|c|c|c|}
\hline & & Mean & Std Dev & Min & Max & $\mathrm{N}$ \\
\hline \multirow[t]{5}{*}{ DIFFPE $=$} & 1 & -0.0013 & 0.0224 & -0.5 & 0.4 & 4,861 \\
\hline & 2 & -0.0010 & 0.0265 & -0.5 & 0.5 & 4,839 \\
\hline & 3 & -0.0009 & 0.0245 & -0.5 & 0.5 & 4,776 \\
\hline & 4 & 0.0001 & 0.0203 & 0.173 & 0.5 & 4,811 \\
\hline & 5 & 0.0002 & 0.0233 & -0.5 & 0.5 & 4,821 \\
\hline
\end{tabular}




\section{TABLE 3}

PANEL B: Sample Partitioned by Sign of Unexpected Earnings

Unexpected Earnings Sample Summary Statistics by DIFFPE Portfolio

$\underline{\mathrm{UE}}>\mathbf{0}$

$\begin{array}{cccccc} & \text { Mean } & \text { Std Dev } & \text { Min } & \text { Max } & \mathrm{N} \\ & & & & & \\ \text { DIFFPE }= & 0.0062 & 0.0185 & 0.0000 & 0.4 & 2,480 \\ 2 & 0.0084 & 0.0256 & 0.0000 & 0.5 & 2,352 \\ 3 & 0.0069 & 0.0222 & 0.0000 & 0.5 & 2,408 \\ 4 & 0.0062 & 0.0223 & 0.0000 & 0.5 & 2,575 \\ 5 & 0.0061 & 0.0242 & 0.0000 & 0.5 & 2,639\end{array}$

$\underline{\mathrm{UE}<\mathbf{0}}$

$\begin{array}{cccccc} & \text { Mean } & \text { Std Dev } & \text { Min } & \text { Max } & \text { N } \\ & & & & & \\ 2 & -0.0105 & 0.0248 & -0.5 & -0.0000 & 2,052 \\ 3 & -0.0103 & 0.0260 & -0.5 & -0.0000 & 2,008 \\ 4 & -0.0083 & 0.0160 & -0.173 & -0.0000 & 1,878 \\ 5 & -0.0083 & 0.0215 & -0.5 & -0.00000 & 1,825\end{array}$


Table 4

Average coefficients, associated t-statistics and adjusted $\mathbf{R}^{2} \mathbf{s}$ return regressions for annual earnings announcements. Sample period covers annual earnings for 1990-1998. Full sample findings.

PANEL A: $\quad R E T_{i t}=a_{0}+a_{1} U E_{i t}+a_{2} S I Z E_{i t}+\varepsilon_{i t}$

$\begin{array}{ccccc}\text { DIFFPE } & \text { UE } & \text { SIZE } & \text { Adj.R }{ }^{2} & \text { NOBS } \\ 1 & 0.198 & -0.00 & 0.58 & 4,858 \\ & (4.57) & (-3.28) & & \\ 2 & 0.150 & 0.00 & 0.30 & 4,830 \\ & (4.02) & (0.20) & & \\ 3 & 0.246 & -0.00 & 0.87 & 4,769 \\ & (5.58) & (-3.69) & & \\ 4 & 0.141 & -0.00 & 0.21 & 4,804 \\ & (2.86) & (-2.00) & & \\ 5 & 0.255 & -0.00 & 0.97 & 4,816\end{array}$




\section{Table 4 (continued)}

Average coefficients, associated t-statistics and adjusted $R^{2}$ s return regressions for annual earnings announcements. Sample period covers annual earnings for 1990-1998. Full sample findings.

\begin{tabular}{|c|c|c|c|c|c|}
\hline ANEL B: & $E T_{i t}=b_{0}+$ & $P_{i t}+b_{2} U E D C$ & $+b_{3} S I Z E$ & & \\
\hline DIFFPE & $U E U P$ & $U E D O W N$ & $S I Z E$ & Adj. $R^{2}$ & NOBS \\
\hline 1 & $\begin{array}{c}0.251 \\
(3.50)\end{array}$ & $\begin{array}{c}0.162 \\
(2.81)\end{array}$ & $\begin{array}{l}-0.00 \\
(-3.09)\end{array}$ & 0.58 & 4,857 \\
\hline 2 & $\begin{array}{c}0.102 \\
(1.88)\end{array}$ & $\begin{array}{c}0.201 \\
(3.61)\end{array}$ & $\begin{array}{c}-0.00 \\
(-0.01)\end{array}$ & 0.31 & 4,830 \\
\hline 3 & $\begin{array}{c}0.264 \\
(3.91)\end{array}$ & $\begin{array}{c}0.231 \\
(3.73)\end{array}$ & $\begin{array}{c}-0.00 \\
(-3.58)\end{array}$ & 0.85 & 4,769 \\
\hline 4 & $\begin{array}{c}0.049 \\
(0.80)\end{array}$ & $\begin{array}{c}0.346 \\
(3.68)\end{array}$ & $\begin{array}{c}00.00 \\
(-2.51)\end{array}$ & 0.33 & 4,804 \\
\hline 5 & $\begin{array}{c}0.201 \\
(3.51)\end{array}$ & $\begin{array}{c}0.362 \\
(4.41)\end{array}$ & $\begin{array}{c}-0.00 \\
(-4.38)\end{array}$ & 1.00 & 4,816 \\
\hline
\end{tabular}


Table 5

Average coefficients, associated t-statistics and adjusted $\mathbf{R}^{2}$ s return regressions for annual earnings announcements. Sample period covers annual earnings for 1990-1998. Findings for NASDAQ FIRMS.

PANEL A: $\quad R E T_{i t}=a_{0}+a_{1} U E_{i t}+a_{2} S I Z E_{i t}+\varepsilon_{i t}$

$\begin{array}{ccccc}\text { DIFFPE } & \text { UE } & \text { SIZE } & \text { Adj. }{ }^{2} & \text { NOBS } \\ 1 & & & & \\ & 0.323 & -0.00 & 0.80 & 2,378 \\ 2 & (4.36) & (-1.67) & & \\ & 0.132 & 0.00 & 0.30 & 2,438 \\ 3 & (2.31) & (1.92) & & \\ & 0.417 & -0.00 & 1.20 & 2,362 \\ 4 & (5.20) & (-2.04) & & \\ & 0.132 & 0.00 & 0.05 & 2,328 \\ 5 & (1.76) & (0.27) & & \\ & 0.360 & -0.00 & 0.66 & 2,393\end{array}$


Table 5

Average coefficients, associated t-statistics and adjusted $R^{2}$ s return regressions for annual earnings announcements. Sample period covers annual earnings for 1990-1998. Findings for NASDAQ FIRMS.

\begin{tabular}{|c|c|c|c|c|c|}
\hline PANEL B: & $E T_{i t}=b_{0}$ & $P_{i t}+b_{2} U E D C$ & $+b_{3} S I Z E$ & & \\
\hline DIFFPE & $U E U P$ & $U E D O W N$ & $S I Z E$ & $\operatorname{Adj} . R^{2}$ & NOBS \\
\hline 1 & $\begin{array}{c}0.439 \\
(3.20)\end{array}$ & $\begin{array}{l}0.266 \\
(2.85)\end{array}$ & $\begin{array}{c}-0.00 \\
(-1.48)\end{array}$ & 0.80 & 2,378 \\
\hline 2 & $\begin{array}{c}0.055 \\
(0.67)\end{array}$ & $\begin{array}{c}0.213 \\
(2.51)\end{array}$ & $\begin{array}{c}0.00 \\
(1.70)\end{array}$ & 0.33 & 2,438 \\
\hline 3 & $\begin{array}{l}0.275 \\
(2.52)\end{array}$ & $\begin{array}{c}0.616 \\
(4.70)\end{array}$ & $\begin{array}{c}-0.00 \\
(-2.41)\end{array}$ & 1.31 & 2,362 \\
\hline 4 & $\begin{array}{c}0.064 \\
(0.71)\end{array}$ & $\begin{array}{c}0.321 \\
(2.06)\end{array}$ & $\begin{array}{c}-0.00 \\
(-0.03)\end{array}$ & 0.09 & 2,328 \\
\hline 5 & $\begin{array}{l}0.210 \\
(2.05)\end{array}$ & $\begin{array}{r}0.861 \\
(4.35)\end{array}$ & $\begin{array}{c}-0.00 \\
(-1.69)\end{array}$ & 0.95 & 2,393 \\
\hline
\end{tabular}


Table 6

Average coefficients, associated t-statistics and adjusted $\mathbf{R}^{2}$ s return regressions for annual earnings announcements. Sample period covers annual earnings for 1990-1998. Findings for NYSE FIRMS.

PANEL A: $\quad R E T_{i t}=a_{0}+a_{1} U E_{i t}+a_{2} S I Z E_{i t}+\varepsilon_{i t}$

$\begin{array}{ccccc}\text { DIFFPE } & \text { UE } & \text { SIZE } & \text { Adj.R }{ }^{2} & \text { NOBS } \\ 1 & 0.100 & -0.00 & 0.30 & 2,428 \\ & (2.01) & (-2.37) & & \\ 2 & 0.167 & -0.00 & 0.50 & 2,446 \\ & (3.75) & (-0.61) & & \\ 3 & 0.131 & -0.00 & 0.52 & 2,408 \\ & (2.79) & (-2.68) & & \\ 4 & 0.154 & -0.00 & 0.28 & 2,478 \\ & (2.48) & (-1.71) & & \\ 5 & 0.192 & -0.00 & 1.17 & 2,426\end{array}$


Table 6

Average coefficients, associated t-statistics and adjusted $R^{2}$ s return regressions for annual earnings announcements. Sample period covers annual earnings for 1990-1998. Findings for NYSE FIRMS.

\begin{tabular}{|c|c|c|c|c|c|}
\hline PANEL B: & $E T_{i t}=b_{0}$ & $P_{i t}+b_{2} U E D C$ & $+b_{3} S I Z E_{i}$ & & \\
\hline DIFFPE & $U E U P$ & $U E D O W N$ & SIZE & Adj. $R^{2}$ & NOBS \\
\hline 1 & $\begin{array}{c}0.153 \\
(2.00)\end{array}$ & $\begin{array}{r}0.055 \\
(0.78)\end{array}$ & $\begin{array}{c}-0.00 \\
(-2.14)\end{array}$ & 0.29 & 2,428 \\
\hline 2 & $\begin{array}{c}0.177 \\
(2.68)\end{array}$ & $\begin{array}{c}0.157 \\
(2.36)\end{array}$ & $\begin{array}{c}-0.00 \\
(-0.55)\end{array}$ & 0.46 & 2,446 \\
\hline 3 & $\begin{array}{c}0.237 \\
(3.00)\end{array}$ & $\begin{array}{c}0.065 \\
(1.07)\end{array}$ & $\begin{array}{c}-0.00 \\
(-2.35)\end{array}$ & 0.59 & 2,408 \\
\hline 4 & $\begin{array}{c}0.037 \\
(0.45)\end{array}$ & $\begin{array}{c}0.347 \\
(3.22)\end{array}$ & $\begin{array}{c}0.00 \\
(-2.22)\end{array}$ & 0.44 & 2,478 \\
\hline 5 & $\begin{array}{l}0190 \\
(3.15)\end{array}$ & $\begin{array}{l}0.195 \\
(2.60)\end{array}$ & $\begin{array}{l}-0.00 \\
(-3.55)\end{array}$ & 1.13 & 2,426 \\
\hline
\end{tabular}


Figure 1: Monthly Market P/E

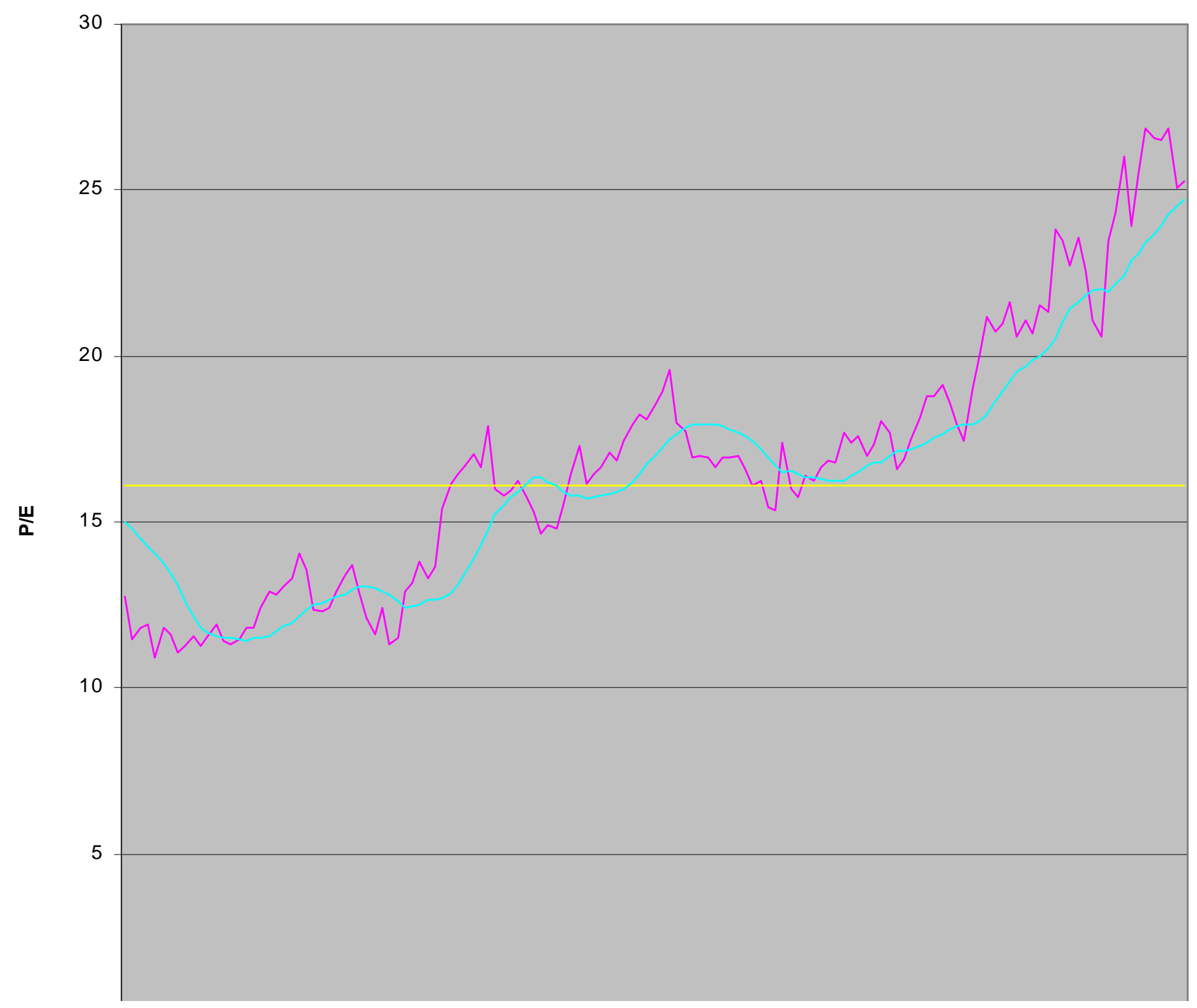

Monthly P/E Average P/E Rolling P/E 
Figure 2: Earnings response coefficients by market level

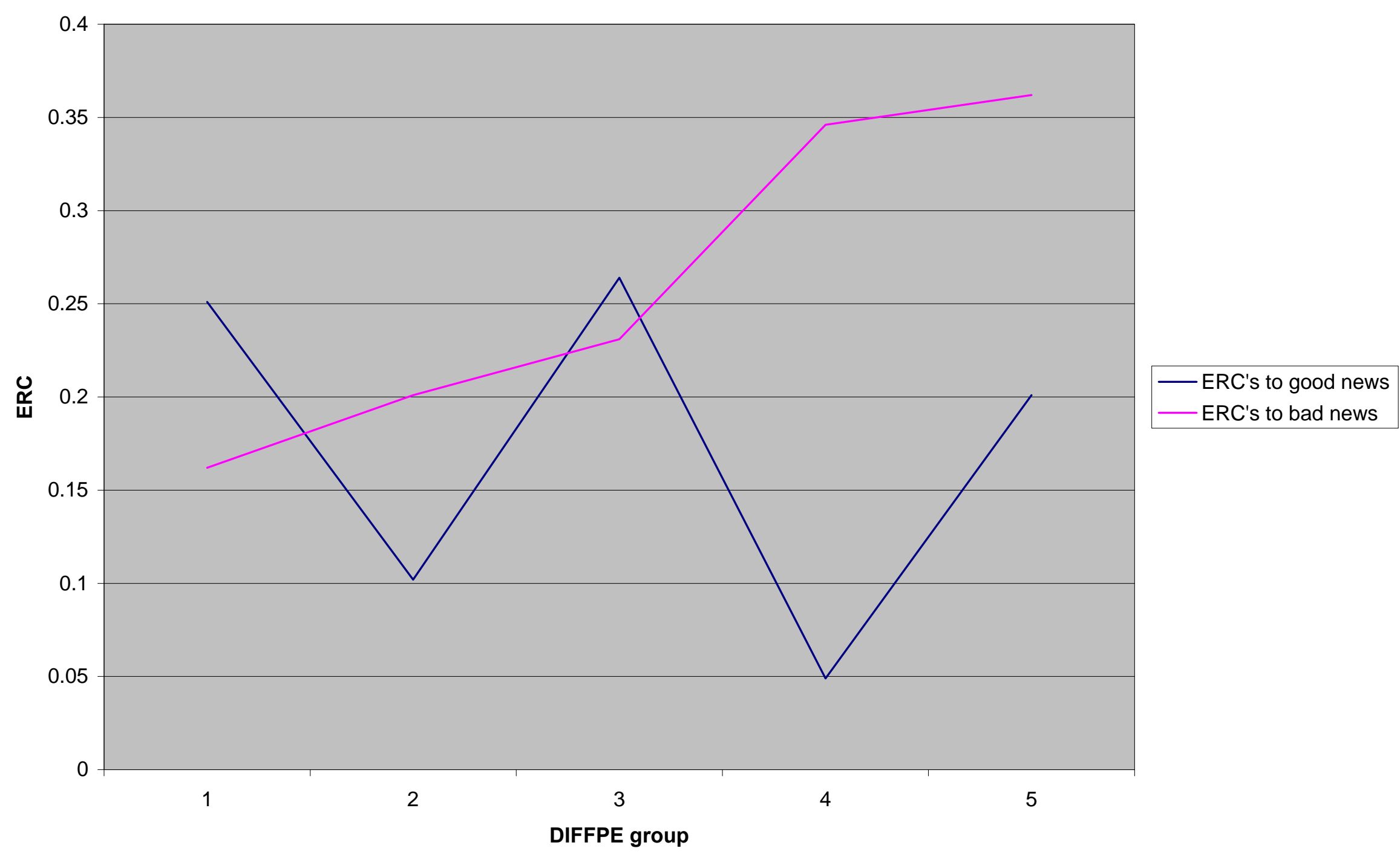


Figure 3: Difference in Good and Bad News ERC's by Market Level

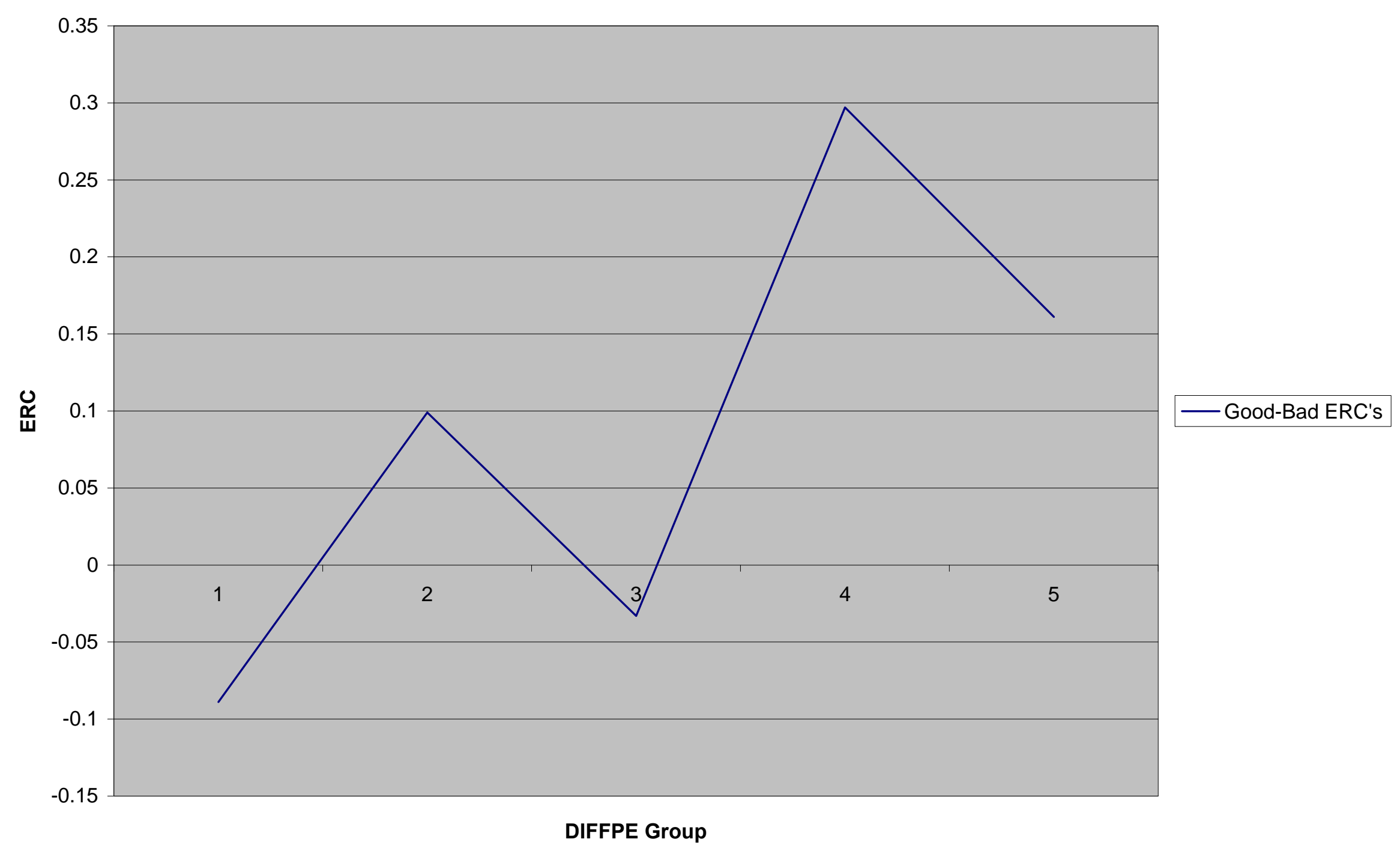

